\title{
実験と解析による曲げロールの押込み量の導出 （眼鏡フレーム用チタン合金線材の高精度ロール曲げ）
}

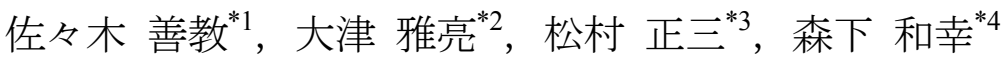
田中 大樹 ${ }^{* 4}$, 八木 秀樹 ${ }^{* 5}$, 関根 雄一郎*6, 浅川 基男 ${ }^{* 7}$

\section{Deriving position of bending roll by experiment and analysis (High precision roll bending of titanium alloy wire for glasses frame)}

\author{
Yoshinori SASAKI ${ }^{* 1}$, Masaaki OTSU ${ }^{* 2}$, Masami MATSUMURA ${ }^{* 3}$, Kazuyuki MORISHITA*4 ${ }^{*}$, \\ Taiki TANAKA $^{* 4}$, Hideki YAGI ${ }^{* 5}$, Yuichiro SEKINE ${ }^{* 6}$ and Motoo ASAKAWA ${ }^{* 7}$ \\ ${ }^{* 1,{ }^{* 4}}$ Industrial Technology Center of Fukui Prefecture \\ 61 Kawaiwashiduka-cho, Fukui-shi, Fukui 910-0102, Japan \\ ${ }^{* 2}$ Department of Mechanical Engineering, University of Fukui \\ 3-9-1 Bunkyo, Fukui-shi, Fukui 910-8507, Japan \\ ${ }^{* 3}$ Department of Technical Development, Fukui Industrial Support Center \\ 61 Kawaiwashiduka-cho, Fukui-shi, Fukui 910-0102, Japan \\ ${ }^{* 5}$ Miwa Kikai Co.,LTD. \\ 72-5 Mitome-cho, Fukui-shi, Fukui 910-3608, Japan \\ ${ }^{* 6,{ }^{* 7}}$ Department of School of Fundamental Science and Engineering, University of Waseda \\ 3-4-1 Okubo, Shinjuku-ku, Tokyo 169-8555, Japan
}

\section{Received 5 March 2014}

\begin{abstract}
A deriving method of bending roll position in forming of glasses frame is proposed. The proposed method requires not the computational simulations but only some simple bending tests. To obtain a relationship between bending roll position and bent curvature which depends on material and cross-sectional shape of bent wire, simplified bending experiments in steady bending condition for getting constant curvature are carried out. The experimentally obtained relationship is used in the formulation of deriving the bending roll position for forming glasses frame having curvature distribution. To validate the proposed method, three different shapes are formed by the proposed and conventional methods. The difference between the designed and formed shapes is evaluated by a sum of absolute of shape deviation, and the value by the proposed method is smaller up to about $50 \%$ than that by the conventional method.
\end{abstract}

Key words : Titanium alloy, Bending, Positioning, Numerical control, Accuracy

\section{1. 緒言}

福井県の眼鏡フレームの生産量は国内シェア $90 \%$ 以上を占めており福井県の重要な産業の一つである(福井県 総合政策部政策統計課編，2012）。眼鏡部品は直接肌に触れることが想定されるため，耐食性と生体適合性が求め

No.14-00131 [DOI: 10.1299/transjsme.2014smm0222]

*1 正員，福井県工業技術センター（T910-0102 福井県福井市川合熟塚町 61 字北稲田 10)

$*_{2}$ 正員, 福井大学 大学院工学研究科 (下910-8507 福井県福井市文京 3 丁目 9 番 1 号)

*3 正員，ふくい産業支援センター（广910-0296 福井県坂井市丸岡町熊堂第 3 号 7 番地 1-16)

*4 福井県工業技術センター

*5 (株) 三輪機械（干910-3608 福井県福井市三留町 72-5)

*6 正員, 早稲田大学 基幹理工学研究科（广169-8555 東京都新宿区大久保 3-4-1）

${ }^{* 7}$ 正員, フェロー, 早稲田大学 基幹理工学研究科

E-mail of corresponding author: y-sasaki@fklab.fukui.fukui.jp 
られる(財団法人日本規格協会編，2008)。そのため近年は純チタンまたはチタン合金が主に使用されている(山 内, 2004). チタン系材料は, それまで使われてきたモネルや洋白等と比べてスプリングバック量が大きく高精度 な加工が難しい(社団法人日本チタン協会編，1996)。眼鏡フレームの曲げ加工は，部位によっては中立線曲率で $300 \mathrm{~m}^{-1}$ 以上の大きな曲率をロール曲げにより加工する．ロール曲げは金型を使うことなく線材に任意の曲率を付 与できるため，プレスによる曲げや，管材に曲率を付与する研究報告(村田他，1994（ 久保木他，2000）と比較 して低コストで多品種少量生産に利点がある．また，被加工材へのダメージが少なく，顔に身につける装飾具と しての美観が求められる眼鏡フレームの加工に適している.

著者らはこれまで，線材の三次元曲げにおけるねじれの要因について報告（Sekine, et al., 2012）しており，線材 の非対称性やロールに対する接触角度の影響を明らかにしてきた，ロール曲げに関するこれまでの研究として， 曽田ら(曾田，小西，1962）はロール押込み曲げとの違いを提示しながら，3 本ロール曲げに関して定常曲げにお ける定性的な基本式を提案している．また，その続報(曾田，小西，1963)では計算図表と併せることで加工形状 が理論解と一致寸ることが報告されている. しかし，直径 $40 \mathrm{~mm}$ のロールを用いて板厚 $1 \mathrm{~mm}$ 以下の材料に 20 $\mathrm{m}^{-1}$ 以下の曲率を付与する加工範囲に限定されており, 高曲率を付与する場合には適用できないことが記述され ている. また山川ら (山川他，1977) は，数值制御による非定常曲げのロール位置の導出方法が提案しているが， 直径 $60 \mathrm{~mm}$ のロールを用いて板厚 $1.6 \mathrm{~mm}$ のSS400 相当鋼板に $16 \mathrm{~m}^{-1}$ 以下の曲率を付与する加工範囲についての 報告であり，その適用範囲は限られる.

加工機の部品には，組み立てに必要なクリアランスが設定されている．また，部品の脱着には許容される誤差 がある．そのため加工機を再構成すると加工条件が変化し，同一のロール配置であっても成形される曲率は変化 寸る.この問題に対してクリアランスを小さくしたり，ロールの位置精度を高めることは有効である．しかし， 同一規格の線材であっても製造ロット毎に成形曲率は変化する．前述の対策は，被加工線材に起因する成形曲率 の変化に対しては効果がないため，工業的には有意義でない，実際の加工現場においても，以前加工した設計形 状を再受注したときに，以前の加工データと同一治具を用いて加工を行っても設計形状を得られない．

加工機の状態や被加工線材のロット変更により加工曲率が変化する場合にも対応可能な加工方法として, 設計 形状の加工前に予め加工機の操作量と加工曲率の関係を把握して, 設計形状の曲率が得られるように加工機の操 作量を設定する方法がある．しかし，この方法は曲率が大きく変化する設計形状を対象とした場合，加工形状が 設計形状に対して大きくズレるという問題がある．そのため職人が数時間かけて試行錯誤しながら調整を行って おり, この工程の省力化が求められている. 少ない試行回数で調整するためには 1 回目の加工形状が設計形状に 近いことが望ましい，曲率変化の大きな設計形状であっても 1 回目から設計形状に近い加工形状が得られる，簡 易で実用的なロール位置の導出方法の確立が求められている.

実際の眼鏡フレーム形状は三次元形状であるが，上記の問題解決の最初の取組みとして本研究では大きな曲率 の付与が必要となる「リム巻きカーブ」(2・1 節で説明する二次元形状 (平面閉曲線) $)$ のロール曲げにおいて, 1 回目の加工形状を従来方法よりも設計形状に近づけることのできるロール押込み量の導出方法を提案し，その 効果を検証する.

\section{2. 眼鏡フレームの構造と曲げ加工機}

\section{$2 \cdot 1$ 眼鏡フレームの定義}

眼鏡フレームの名称(財団法人日本規格協会編，2006) と線材の断面形状を図 1 に示す. 眼鏡のレンズを保持す るためのリング状の部品をリムとよび，その線材断面はレンズを保持するための溝が加工されている。

リムの各種曲線を図 2 に示寸，設計者は正面から見たときのリムの二次元形状を設計する．その設計形状を指 定されたレンズ球面に投影した曲線がリムの三次元形状となる．二次元形状を押出した筒を平面に展開すると， 二次元形状は直線に，三次元形状は $S$ 字状カーブとなる.この $S$ 字状カーブをレンズカーブと定義する. 三次元 設計形状の各点における最大曲率（円筒面上の各点の最大曲率）をリム巻き曲率とし，リム巻き曲率の逆数をリ ム巻きカーブと定義する．本研究ではこのリム巻きカーブの加工を対象とした. 


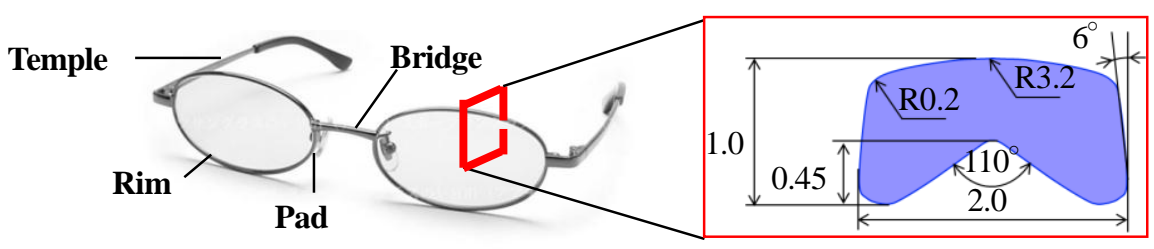

Fig. 1 Names of glasses frame parts and sectional shape of wire (in $\mathrm{mm}$ )

\section{$2 \cdot 2$ リム曲げの機構部}

眼鏡フレーム専用の曲げ加工機の装置全体を図 3(a)，加工部の全ロール配置を図 3(b)，加工部のうちリム巻き カーブ加工に関する概要図を図 3(c)に示す．曲げモーメントが作用していない状態での線材送り方向を $x$ 軸，線 材厚み方向を $y$ 軸，線材幅方向を $z$ 軸と定義する．上流側から順番に線材に対して $y$ 軸方向に作用するロールに 数字を, $z$ 軸方向に作用寸るロールにアルファベットの名前をつける. ロール C 以降全体が $z$ 方向にスライドす るとともにロール C を中心に回転する構造となっており, さらにロール 8 については $y$ 方向へスライドする構造 となっている. 実際のリム加工では, ロールC 以降全体のスライド量を固定したのち, 線材の送り量, ロール C を中心とした回転角度，ロール 8 の押込夕量を数值制御することで三次元曲げを行っている.

本研究はリム巻きカーブのみを対象としているため，ロール A〜D およびロール 1〜5 は座屈防止のための線 材拘束ロールとして用いた. 図 3(c)に示すようにロール 8 が $y$ 方向にスライドすることで，ロール 6〜8の 3 つの ロールによって線材が曲げ加工される.

まっすぐな線材とロール 8 が接触する位置を押込み量 0 の基準位置とし, 基準位置からのロール 8 の変位を押 込み量 $h$ とした. ロール 8 の可動範囲は, ロール 7,8 の半径を $r_{7}, r_{8}$, 線材の厚みを $t$ としたとき $r_{7}+t+r_{8}$ であ る. また，ロール 7 とロール 8 の $x$ 軸方向の中心間距離は一定であり，これを $G$ とする.

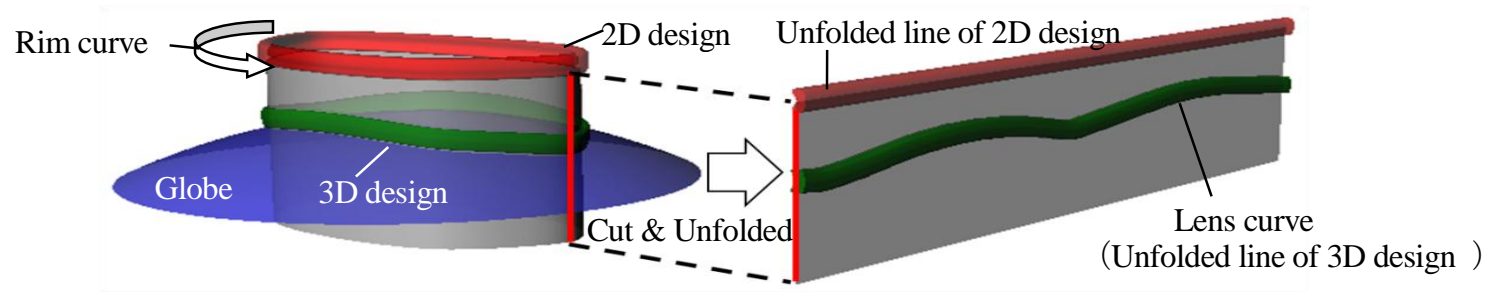

Fig. 2 Definition of rim and lens curves

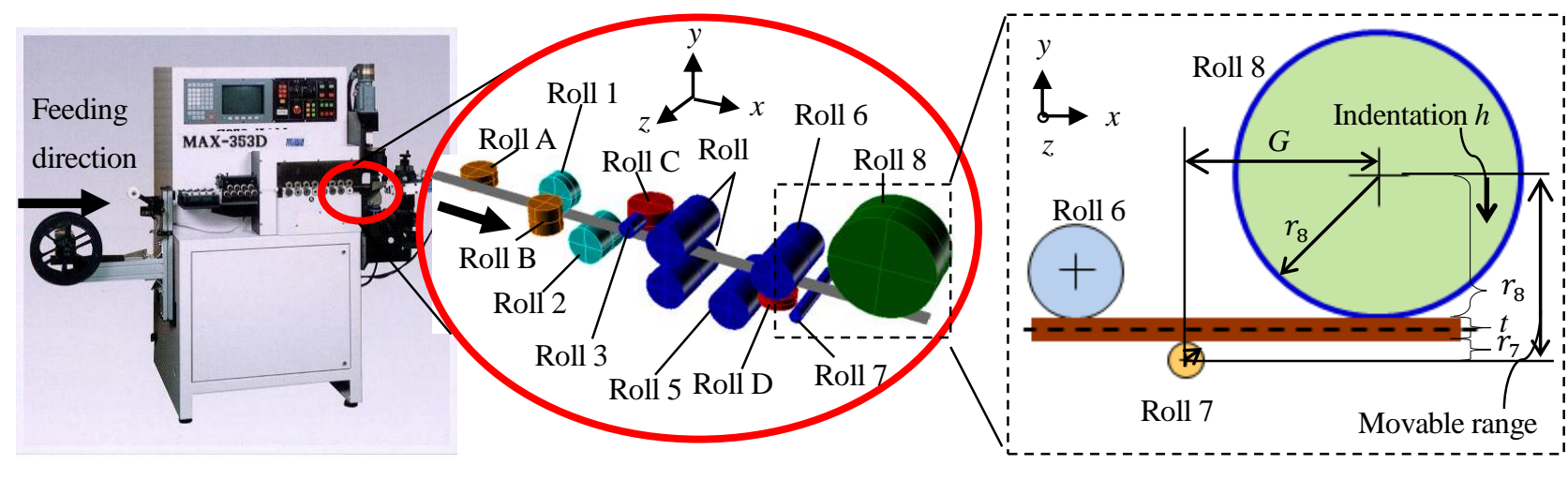

(a) Appearance of bending machine

(b) Layout of rolls

(c) Detailed geometric relationship among rolls 6,7 and 8

Fig. 3 Bending machine 


\section{$2 \cdot 3$ 線材の材質と形状}

供試材には JIS4650の 61 種に相当する $3 \mathrm{Al}-2.5 \mathrm{~V}$ チタン合金で幅 $2.0 \mathrm{~mm} \times$ 厚み $1.0 \mathrm{~mm}$ の平角線と金属眼鏡フ レームとして最も利用されている幅 $2.0 \mathrm{~mm} \times$ 厚み $1.0 \mathrm{~mm}$ のリム線材を用いた. JIS4650 の 61 種の化学成分を表 1 (財団法人日本規格協会編, 2012)に示す.

Table 1 Chemical composition of Ti alloy

\begin{tabular}{c|c|c|c|c|c|c|c}
\multicolumn{9}{c}{ Table 1 Chemical composition of Ti alloy } & \multicolumn{2}{c}{$[$ mass \%] } \\
\hline \hline $\mathrm{N}$ & $\mathrm{C}$ & $\mathrm{H}$ & $\mathrm{Fe}$ & $\mathrm{O}$ & $\mathrm{Al}$ & $\mathrm{V}$ & $\mathrm{Ti}$ \\
\hline$\leqq 0.03$ & $\leqq 0.08$ & $\leqq 0.015$ & $\leqq 0.25$ & $\leqq 0.15$ & $2.50 \sim 3.50$ & $2.00 \sim 3.00$ & Bal. \\
\hline
\end{tabular}

\section{3. 定常曲げ実験および参照データの作成}

本章では，設計形状の加工前に事前に行う定常曲げ実験の説明をする． $3 ・ 1$ 節では定常曲げ実験の手順および 概要を説明する. $3 \cdot 2$ 節では, 定常曲げ実験で測定した一様円弧の曲率半径から加工領域における最大曲げモー メントを求める計算方法を示す. $3 \cdot 3$ 節では，一様円弧と各ロールとの幾何学的関係から得られる情報について 示す. $3 \cdot 4$ 節では, 設計形状の加工時に参照されることとなる定常曲げ実験結果データの作成について説明する.

\section{$3 \cdot 1$ 定常曲げ実験}

定常曲げ実験の概要を図 4 に示す. 図 4(a)に示すように押込み量 0 の初期状態から，図 4(b)に示すように所定 の押込み量 $h$ の位置にロール 8 を固定し, 図 4(c)に示すように成形される曲率が一定になるまで十分に線材を送 る（この状態を「定常状態」と呼ぶ）．定常状態における線材の加工曲率半径を $\rho$, ロール 8 を離脱した線材のス プリングバック後の曲率半径を $\rho^{\prime}$ とする. 以降スプリングバック後の変数には' を付けて表す. また，特に断り がなければ曲率半径は中立線の曲率半径を意味する。押込み量 $h$ と曲率半径 $\rho^{\prime}$ の関係を図 5 に示す.

なお，定常曲げ実験は，一様円弧の内径あるいは外径をノギス等により計測することで中立線の曲率半径 $\rho^{\prime}$ を 求めることができ経済的負担も少ないため，実際の加工現場で容易に実施可能である.

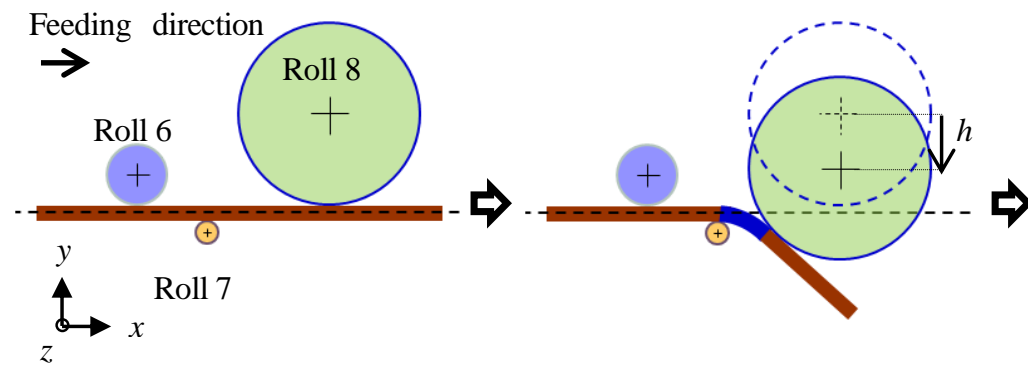

(a) Initial state (b) Indentation in specified quantity

Fig. 4 Steady bending experiment process

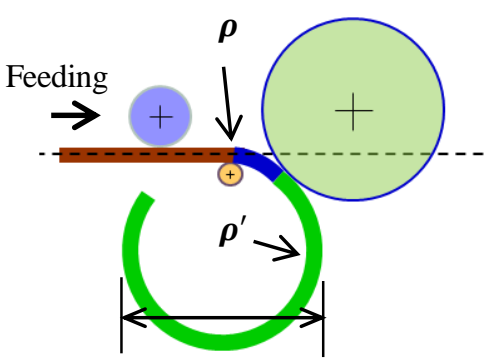

(c) Diameter measurement after being steady state

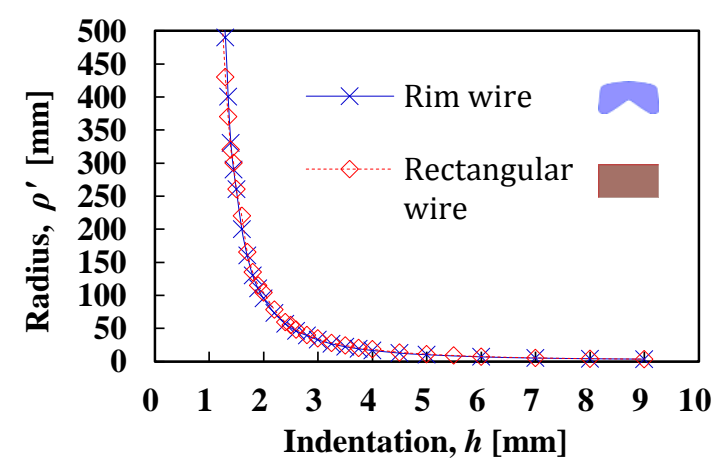

(a) Radius

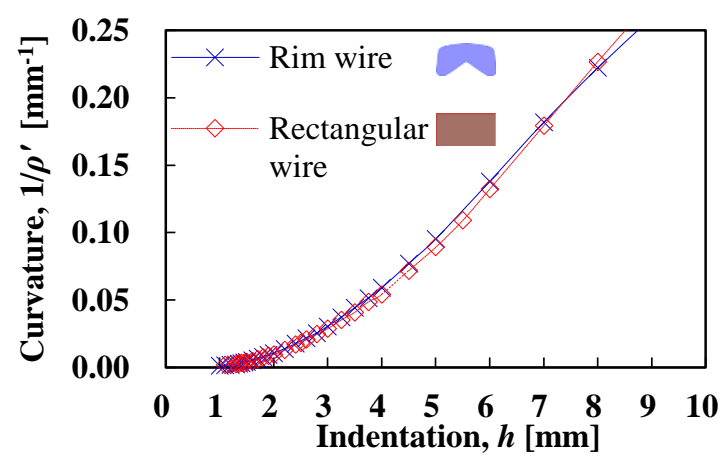

(b) Curvature

Fig. 5 Relationship between radius $\rho^{\prime}$ and indentation $h$ 


\section{$3 \cdot 2$ 加工領域の最大曲げモーメントの導出}

線材をヤング率 $E$, 耐力 $Y$ の弾完全塑性体と仮定し, 弾性限界曲率半径を $\rho_{E}$, 弾性限界モーメントを $M_{E}$, 断面 二次モーメントを $I$ としたとき, 曲げモーメント $M\left(M>M_{E}\right)$ と曲率半径 $\rho$ の関係は式(1)（社団法人日本塑性加工 学会編，1995）となることが知られている.

$$
M=\frac{3}{2} M_{E}\left[1-\frac{1}{3}\left(\frac{\rho}{\rho_{E}}\right)^{2}\right] \quad\left(\text { ただし, } M_{E}=\frac{E I}{\rho_{E}}\right)
$$

スプリングバックは, 曲げモーメント $M$ による曲げ加工後の線材に, 反対の曲げモーメントーMが付加され, 曲 げモーメント 0 となる過程で発生する弾性変形と解釈できる.

$$
\frac{1}{\rho^{\prime}}=\frac{1}{\rho}-\frac{M}{E I}
$$

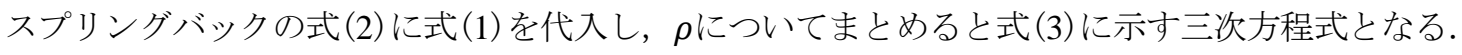

$$
\rho^{3}-2 \rho_{E}^{3}\left(\frac{1}{\rho^{\prime}}+\frac{3}{2 \rho_{E}}\right) \rho+2 \rho_{E}^{3}=0
$$

式(3) の実数解は最大で 3 つあるが，曲率半径が塑性域という条件 $\left(0<\rho<\rho_{E}\right)$ から適当な解は式(4) とな る.

$$
\rho=2 \rho_{E} \sqrt[3]{Z} \cos \left(\frac{\xi-2 \pi}{3}\right) \quad\left(\text { ただし, } Z=\sqrt{\left(\frac{2 \rho_{E}}{3 \rho^{\prime}}+1\right)^{3}}, \quad \xi=\cos ^{-1}\left(-\frac{1}{Z}\right)\right)
$$

線材の受けた最大曲げモーメントを $M_{\max }$ とおくと $M_{\max }$ は式(4)を式(1)に代入した式(5)となる.

$$
M_{\max }=\frac{3}{2} M_{E}\left\{1-\frac{4}{3}\left[\sqrt[3]{Z} \cos \left(\frac{\xi-2 \pi}{3}\right)\right]^{2}\right\}
$$

以上により，定常曲げ実験で測定した一様円弧の曲率半径 $\rho^{\prime}$ から，定常状態においてロール 7 近傍の加工点に 生じている最大曲げモーメント $M_{\max }$ が得られる.

\section{$3 \cdot 3$ 曲げモーメントに寄与する押込み量の導出}

定常状態における曲げモーメント分布および曲率分布を図 6(a) に示す. 線材とロール 7 との接点を点 $\mathrm{C}_{7}$, ロー ル 8 との接点を点 $\mathrm{C}_{8}$ とする. 点 $\mathrm{C}_{7}$ から点 $\mathrm{C}_{8}$ 間の曲率 $\kappa$ は, 式(2)に示すとおり作用する曲げモーメントに応じ て $1 / \rho$ から $1 / \rho^{\prime}$ の範囲となる. それらの線材も, 順次送りだされて点 $\mathrm{C}_{8}$ を通過するとスプリングバックが完了し 曲率は $1 / \rho^{\prime}$ となる. ここで, 定常状態において線材の送りを止め, 図 6(b) に示寸ように, 押込み量を減少させて いきロール 8 と線材が接触し，かつ，曲げモーメントが発生しない状態を仮定する（この状態を「無負荷接触状 態」と呼ぶ)。曲げモーメントがなくなるため点 $\mathrm{C}_{7}$ から点 $\mathrm{C}_{8}$ 間の線材の曲率は，点 $\mathrm{C}_{8}$ を通過した線材と同様ス プリングバックが完了し $1 / \rho^{\prime}$ となる. よって点 $\mathrm{C}_{7}$ 以降は曲率 $1 / \rho^{\prime}$ の一様円弧となる.

このとき，点 $\mathrm{C}_{7}$ の上流側線材には塑性加工領域が存在するが，これを無視すると幾何学的関係から次のことが いえる. ロール 8 の中心と一様円弧中心を結んだ線分の長さは, 一様円弧の半径 $\rho^{\prime}$, 線材厚さ $t$, ロール 8 の半径 $r_{8}$ を用いて $\rho^{\prime}+0.5 t+r_{8}$ となる. この線分が $y$ 軸とな寸角度を $\theta$ とおくと, ロール 7 とロール 8 の中心間の $x$ 方 向距離は $G$ で一定のため式(6)が成り立つ. 
$\sin \theta=\frac{G}{\rho^{\prime}+0.5 t+r_{8}}$

押込み量 0 から線材に接触するまでのロール 8 の移動量を $h_{C}$ とおくと $h_{C}$ は式(7) となり $\rho^{\prime}$ の関数となる.

$$
h_{C}=\left(\rho^{\prime}+0.5 t+r_{8}\right)(1-\cos \theta)
$$

接触のための移動量 $h_{C}$ は, 図 6(b)の破線で示す全押込み量 0 のロール 8 から実線で示すロール 8 の位置への移 動距離である. 全押込み量 $h$ が 0 から $h_{C}$ の範囲においては, ロール 8 と線材は接触しないため曲げモーメントは 発生しない. 全押込み量 $h$ のうち接触のための移動量 $h_{C}$ は曲げモーメントの発生に寄与しない移動量であって, 全押込み量 $h$ から $h_{C}$ を引いた移動量 $h_{M}$ が曲げモーメントに寄与する移動量とみなせる.

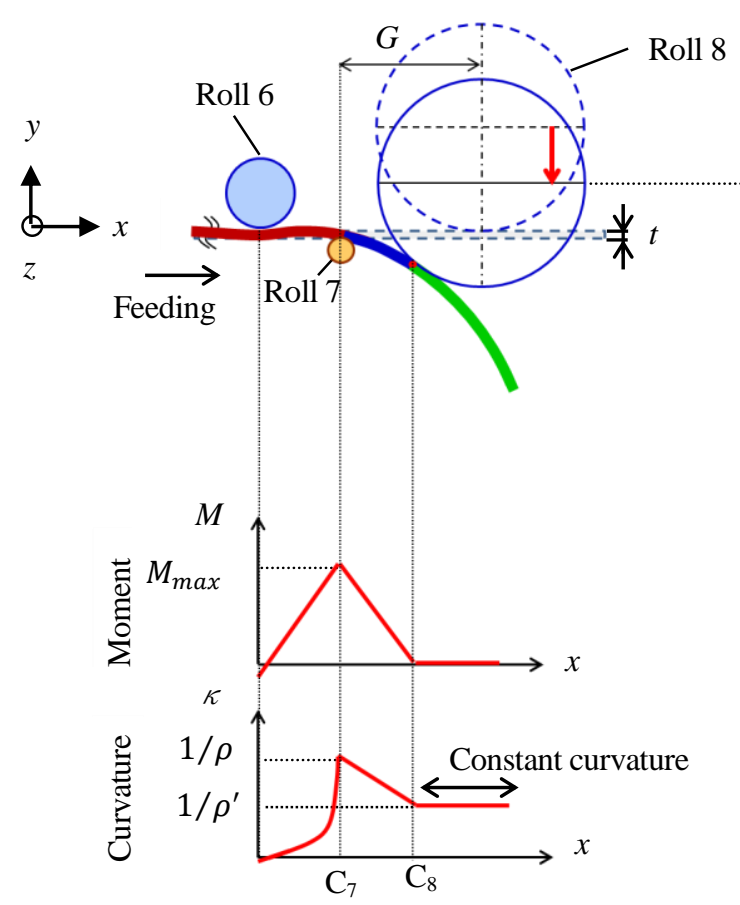

(a) Moment and curvature distribution at steady state

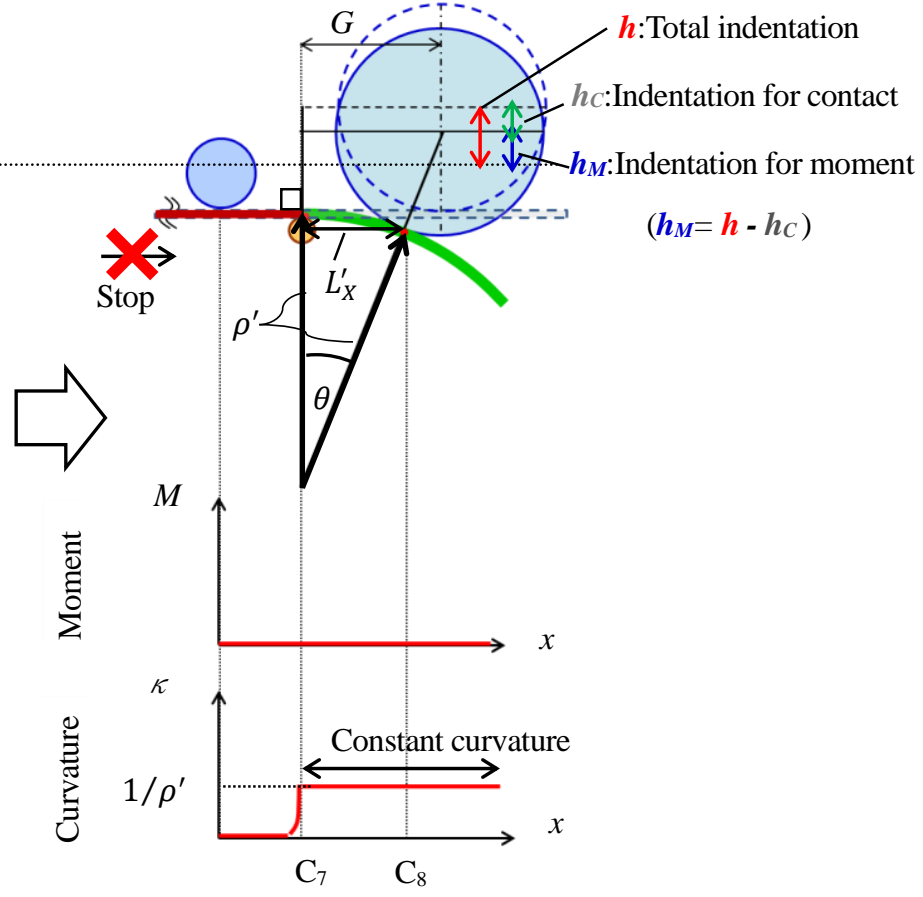

(b) Decreasing indentation to zero moment after stopping wire feeding

Fig. 6 Geometric relations of contact state with rolls and wire

\section{$3 \cdot 4$ 参照データの作成}

無負荷接触状態において点 $\mathrm{C}_{7}$ から点 $\mathrm{C}_{8}$ までの $x$ 方向距離を無負荷モーメントアーム $L_{X}^{\prime}$ と定義する. 幾何学的 関係から無負荷モーメントアーム $L_{X}^{\prime}$ は式(8)に示寸一様円弧 $\rho^{\prime}$ の関数となる.

$$
L_{X}^{\prime}=\left(\rho^{\prime}+0.5 t\right) \sin \theta=\frac{\left(\rho^{\prime}+0.5 t\right) G}{\rho^{\prime}+0.5 t+r_{8}}
$$

実験機のロール 8 の半径 $r_{8}$, 線材の厚み $t$, ロール 7 とロール 8 の $x$ 軸方向の中心間距離 $G$ を式 $(8)$ に入れたと きの $\rho^{\prime}$ と $L_{X}^{\prime}$ の関係を図 7(a)に示す.

図 7(a)の縦軸 $\rho^{\prime}$ を式(4)および式(5)に代入することで, ロール 7 近傍の最大曲げモーメント $M_{\text {max }}$ に変換すると, 図 7(b)に示寸無負荷モーメントアーム $L_{X}^{\prime}$ と最大曲げモーメント $M_{\max }$ の関係が得られる.

また, 図 7(a)の縦軸 $\rho^{\prime}$ を式(8) に代入することで, 図 7(c)に実線で示寸無負荷モーメントアーム $L_{X}^{\prime}$ と接触のため の移動量 $h_{C}$ の関係が得られる，同様に，図 7(a)の縦軸 $\rho^{\prime}$ を図 5(a)に示した定常曲げ実験の全押込み量 $h$ に変換す 
ると, 図 7(c)にメ印で示寸無負荷モーメントアーム $L_{X}^{\prime}$ と全押込み量 $h$ の関係が得られる. 全押込み量 $h$ と接触の ための移動量 $h_{C}$ の差から図 7(c)に○印で示す無負荷モーメントアーム $L_{X}^{\prime}$ と曲げモーメントに寄与する移動量 $h_{M}$ の関係が得られる.

ロール 8 の全押込み量 $h$ が $h=h_{C}$ から $h=h_{C}+h_{M}$ まで変化する間, 最大曲げモーメント $M_{\max }$ は押し込み量に比例 するとみなして両者の関係を線形近似する. 図 7(b)の最大曲げモーメント $M_{\max }$ を図 7(c)の曲げモーメントに寄与 する移動量 $h_{M}$ で割ることで, 図 7(d)に示寸無負荷モーメントアーム $L_{X}^{\prime}$ と単位曲げモーメントに寄与する移動量 $h_{M}$ 当たりの発生曲げモーメント係数 $k\left(M_{\max } / h_{M}\right)$ の関係が得られる.

次章で説明する設計形状を加工するための押込み量の導出では, 無負荷モーメントアーム $L_{X}^{\prime} を$ 变数とする関数 化された図 7(d)が参照され，対応した発生曲げモーメント係数 $k\left(L_{X}^{\prime}\right)$ が返される.

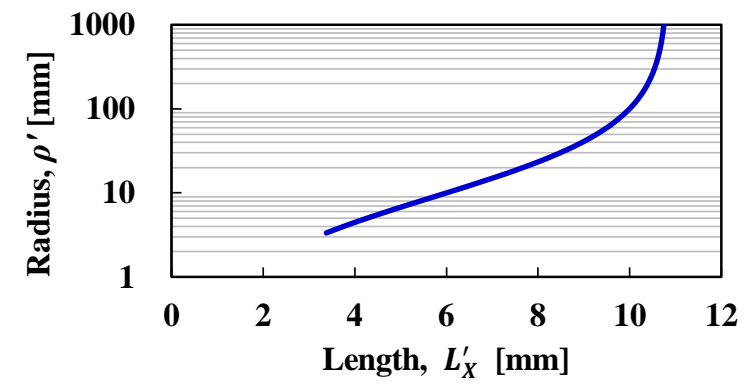

(a) Relationship between radius $\rho^{\prime}$ and $L_{X}^{\prime}$

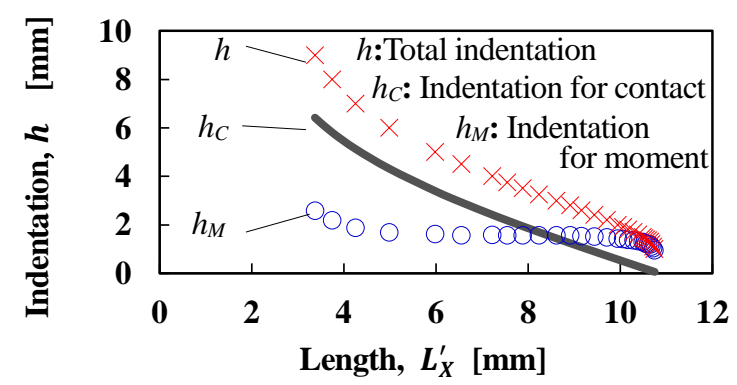

(c) Relationship among indentation $h, h_{C}, h_{M}$ and $L_{X}^{\prime}$

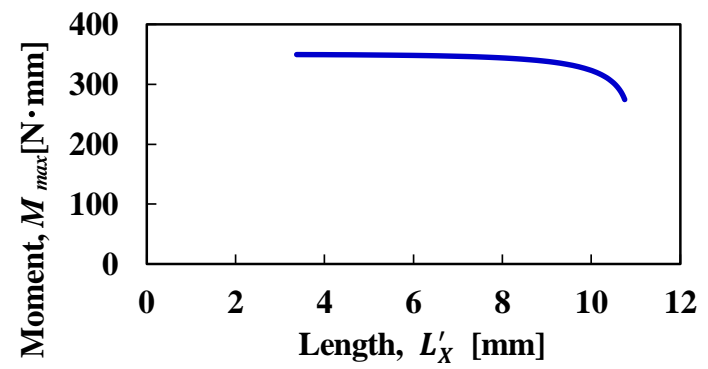

(b) Relationship between moment $M_{\max }$ and $L_{X}^{\prime}$

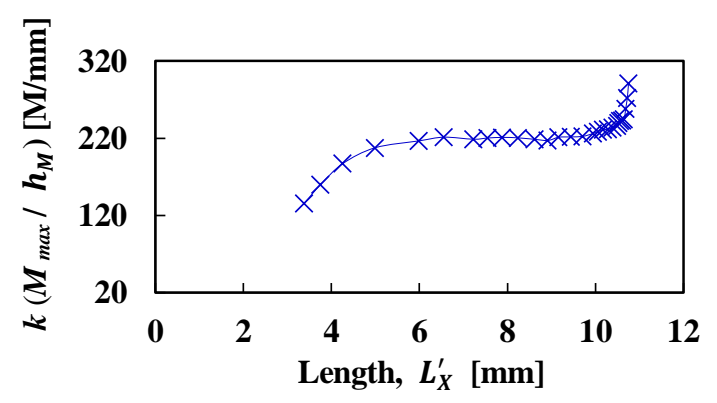

(d) Relationship between $k\left(M_{\max } / h_{M}\right)$ and $L_{X}^{\prime}$

Fig. 7 Relationship among $L_{X}^{\prime}$ and variables

\section{4. 設計形状を加エするためのロール 8 の押込み量の導出}

最初に設計形状とロール配置との幾何学的関係から得られる設計形状に係る変数について，図 8 を参照しなが ら説明する. 図 8 中に実線で示寸設計形状の中立線に対して, $r_{7}+0.5 t$ だけ内側にオフセットした点線で示す卜 ラック 7 を描画する. 同様に, $r_{8}+0.5 t$ だけ外側にオフセットした一点鎖線で示すトラック 8 を描画する. ロール 7 がトラック 7 上を，ロール 8 がトラック 8 上を移動する場合，各ロールと線材とは接することになる．

ここで, 設計形状のある点 $n$ がロール 7 と接している場合に着目して, 無負荷接触状態のロール 8 の中心位置, 接触ための移動量および無負荷モーメントアームを求める. 定常曲げ実験で定義した各種変数と区別するため, 点 $n$ の曲率半径を $\rho^{\prime}(n)$, 無負荷モーメントアームを $L_{X}^{\prime}(n)$, 押込み量 0 から線材とロール 8 との接触のための移 動量を $H_{C}(n)$ と記述する.

ある点 $n$ の曲率半径 $\rho^{\prime}(n)$ は設計形状から既知であるが, ある点 $n$ がロール 7 と接している場合の $x$ 方向は, 図 6(b)に示寸ようにロール 7 上流側の線材方向であるから点 $n$ の接線方向となる. また， ロール 7 とロール 8 の $x$ 方向中心間距離は $G$ で一定であることから, 無負荷モーメントアーム $L_{X}^{\prime}(n)$ および接触のための移動量 $H_{C}(n)$ は 作図により求めることができる.

具体的には, 点 $n$ での設計形状に対する垂線を $x$ 方向に距離 $G$ だけ平行移動させたとき，垂線とトラック 8 と の交点が設計形状に対して無負荷接触状態となるロール 8 の中心位置となる. この位置を中心に半径 $r_{8}+0.5 t$ の円 
を描画し，その円と設計形状の中立線との交点が点 $\mathrm{C}_{8}$ となる. 点 $\mathrm{C}_{7}$ は点 $n$ であるから点 $\mathrm{C}_{7}$ 点 $\mathrm{C}_{8}$ 間 $x$ 方向長さ を測り無負荷モーメントアーム $L_{X}^{\prime}(n)$ とする. 押込み量 0 のロール 8 の中心位置と無負荷接触状態のロール 8 の 中心位置の長さを測り，接触のための移動量 $H_{C}(n)$ とする. 以上のようにして幾何学的に $L_{X}^{\prime}(n)$ および $H_{C}(n)$ を把 握する.

最後に，曲げモーメントに寄与する移動量を導出する．定常曲げ実験で定義した各種変数と区別するため，曲 げモーメントに寄与する移動量を $H_{M}(n)$, 加工に要する曲げモーメントを $M(n)$ と記述する. 加工に要する所要曲 げモーメント $M(n)$ は，式(4)および式(5)の $\rho^{\prime}$ に $\rho^{\prime}(n)$ を代入することで求まる.

ここで，無負荷接触状態からのロール 8 の押込み量と発生する曲げモーメントは比例するとともに，その比例 定数は無負荷モーメントアーム $L_{X}^{\prime}(n)$ に依存すると仮定する．定常曲げ実験で作成した参照データ図 7(d)を用い て無負荷モーメントアーム $L_{X}^{\prime}(n)$ に対応した発生曲げモーメント係数 $k\left(L_{X}^{\prime}\right)$ を取得する. 所要曲げモーメント $M(n)$ を曲げモーメント係数 $k\left(L_{X}^{\prime}\right)$ で除した值を $H_{M}(n)$ とし, $H_{C}(n)$ と $H_{M}(n)$ の和をある点 $n$ を加工するための全押 込み量 $H(n)$ とする. 設計形状の中立線を $0.1 \mathrm{~mm}$ 毎に分割し, 上述した作業により各点の全押込み量を求めるこ とで，設計形状を加工するための線材の送り量とロール 8 の全押込み量を決定した.

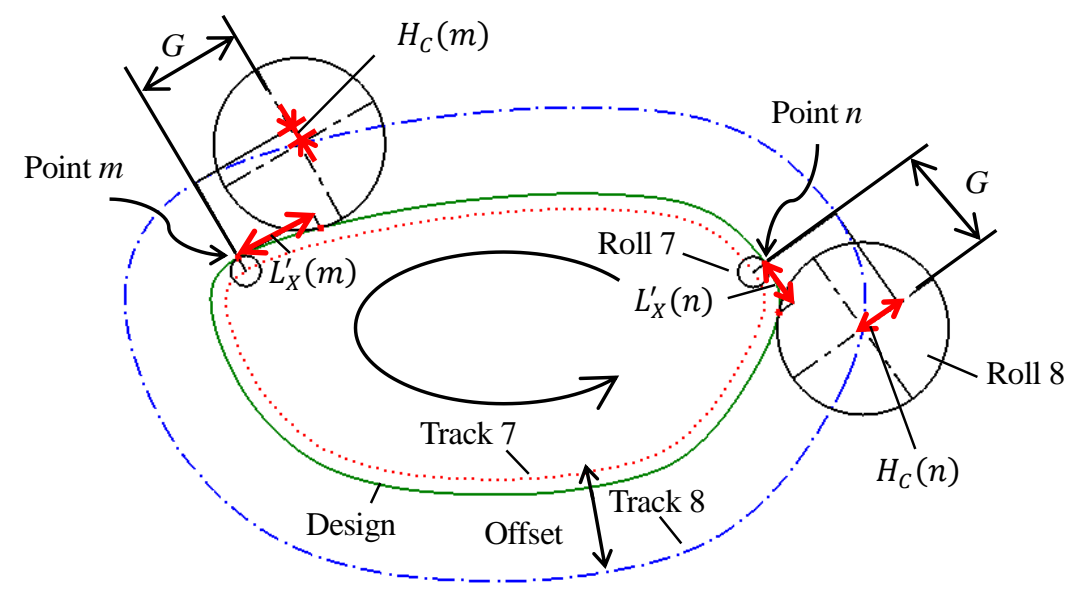

Fig. 8 Position relations among design shape and trajectories of center of roll 7 (track 7) and roll 8 (track 8) in contact state

\section{5. 実証実験と評価}

\section{$5 \cdot 1$ 実験方法}

図 9 に示寸 3 種類の設計形状についてリム線材を加工する実験を行った. 設計形状 1 は実際の眼鏡の形状であ る. 設計形状 2, 設計形状 3 は一辺 $60 \mathrm{~mm}$ の正方形のコーナを R $5.0 \mathrm{~mm}, \mathrm{R} 7.5 \mathrm{~mm}$ でフィレットした形状である.

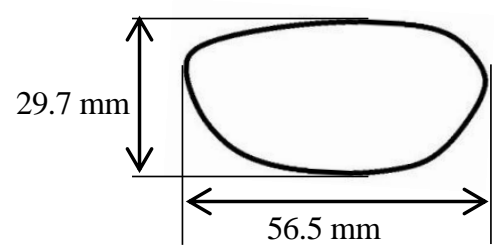

(a) Design 1

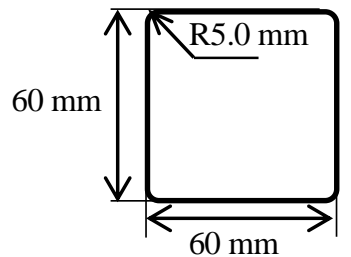

(b) Design 2

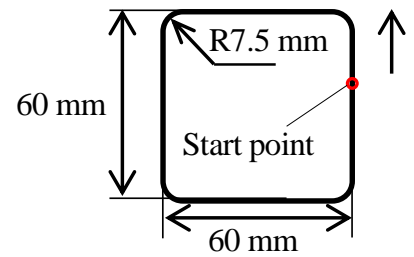

(c) Design 3

Fig. 9 Design shapes

設計形状を加工するためのロール 8 の押込み量の導出は 2 つ方法により行った. 方法 1 は今回提案する 3 , 4 章で説明した方法である. 比較対象となる方法 2 は従来技術によるもので，具体的には，図 10(a)に示寸定常曲 げ実験の押込み量と曲率の関係を設計形状の曲率に 1 対 1 で対応させる方法である.

設計形状 3 を例として, 方法 1 および方法 2 によるロール 8 の押込み量の導出結果を図 10(b)に示寸. 横軸 $L$ は 加工開始点からの距離で, 縦軸 $H$ はロール 8 の全押込み量である. 設計形状 3 のコーナ部前後の押込み量に着目 
すると, 方法 1 では $1.0 \mathrm{~mm}$ から $6.0 \mathrm{~mm}$ 一連続的に変化している. 一方, 方法 2 では設計形状の曲率に対して, 直線部分（曲率 0）については押込み量約 $1.0 \mathrm{~mm}, \mathrm{R} 7.5 \mathrm{~mm}$ （曲率約 $0.133 \mathrm{~mm}^{-1}$ ) 部については押込み量約 $6.0 \mathrm{~mm}$ の矩形波状となる.

加工形状の評価には三次元形状測定器（㑣ミツトヨ製 Super QV606-Pro）を用いた。加工線材の輪郭の形状を 測定し，その座標データを CAD ソフトフェアに取り込み，中立線および中立線上の曲率を求めた. 設計形状 1 に ついては設計形状の約 9 割に相当する $136 \mathrm{~mm}$ を, 設計形状 2 および設計形状 3 については一ヶ所のコーナとそ の前後約 $5 \mathrm{~mm}$ を評価対象とした.

設計形状 3 を例として加工形状の曲率と設計形状の曲率の位置合わせ方法を図 11 に示す．赤線は設計形状の 曲率，青および紫線は加工物の曲率である．加工物の曲率には明確な境界がないため，曲率偏差の絶対值総和が 最小となるように比較開始位置をオフセットして位置決めを行った．最小となった曲率偏差の絶対值総和を $S$ と し，評価対象の線材長さ $l$ で割った単位長さあたりの絶対值偏差量を数值的評価とした.

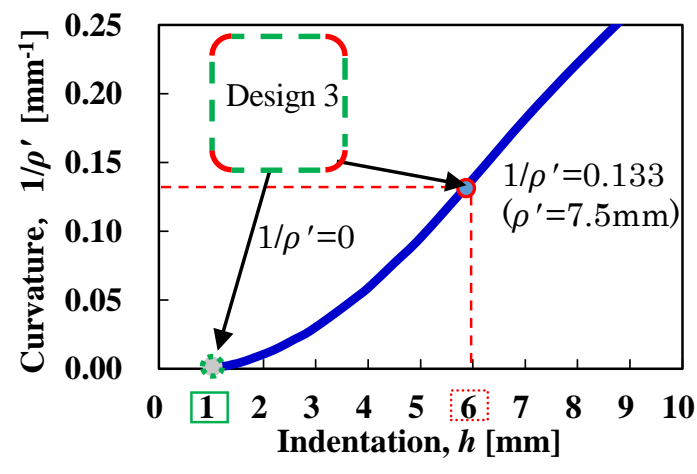

(a) Derivation process by method 2

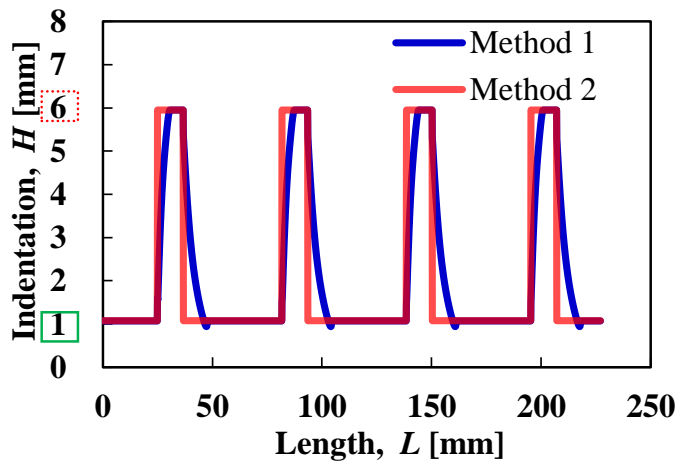

(b) Comparison of indentations by method 1 and method 2

Fig. 10 Derivation process and comparison of derived results by methods 1 and 2 for design 3

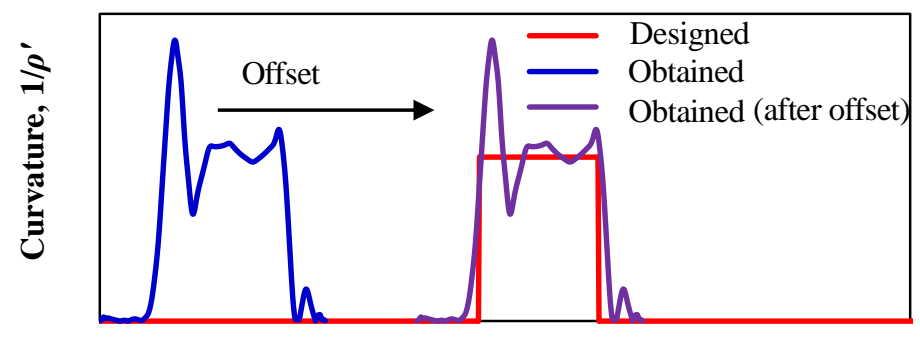

Length, $L$

Fig. 11 Fitting method of bent rim shape curvature and design 3 shape curvature by changing offset level

\section{$5 \cdot 2$ 実験結果および考察}

加工物の形状および数值的評価結果を表 2 に示寸. 加工形状の外観について, 設計形状 1 では方法 1 と方法 2 に大きな違いは見られなかった。設計形状 2 および設計形状 3 では，方法 1 による加工物は概ね設計通りとなる のに対し, 方法 2 にる加工物のコーナが曲がり寸ぎとなった。単位長さあたりの絶対值偏差量を比較すると, 全ての設計形状において, 方法 1 の場合の方が方法 2 の場合よりも小さくなっており, 設計形状の曲率に近づい ていることが確認された.

方法 2 では, 設計形状 2 , 設計形状 3 のように曲率 0 の直線から円弧部に差し掛かる曲率変化が急峻な個所で, 曲率に対応した一律の押込み量で押込むことにより過大な曲げモーメントが発生するためと考えられる. 方法 1 では，接触のための移動量と曲げモーメントに寄与する移動量に分けて全押し込み量を決定することで，過大な 曲げモーメントが発生することを回避できたと考えられる. 
Sasaki, Otsu, Matsumura, Morishita, Tanaka, Yagi, Sekine and Asakawa,

Transactions of the JSME (in Japanese), Vol.80, No.816 (2014)

数值的な評価では, 方法 1 は方法 2 と比較して曲率偏差の絶対值総和を約 3 割から 5 割程度低減することがで きた，方法 1 を実施するために必要な情報は，線材のヤング率，耐力，線材の断面形状，および実機における定 常曲げ実験データという実操業においても容易に得られる情報である. それらの情報から，1回目の加工形状の 精度を従来方法と比較して高めることができるため実用性が高いといえる.

Table 2 Results of bent rim shape by proposed method 1 and reference method 2

\begin{tabular}{l|l|l|l|l|}
\hline \multicolumn{1}{|c|}{ Design 1 } & & \\
\hline \multirow{3}{*}{ Method 1 } & Shape & & & \\
\hline
\end{tabular}

6. 結

言

押込みロールの押込み量を固定し，成形される一様円弧の曲率半径を計測する定常曲げ実験結果において，幾 何学的関係から, 接触のための移動量 $h_{C}$, 曲げモーメントに寄与する移動量 $h_{M}$ および無負荷モーメントアーム $L_{X}^{\prime}$ を導出し，無負荷モーメントアーム $L_{X}^{\prime}$ を変数とする発生曲げモーメント係数 $k$ を得る方法を提案した.

曲率が変化する設計形状を加工する際に, 幾何学的関係から設計形状に対する接触のための移動量 $H_{C}$, および 無負荷モーメントアーム $L_{X}^{\prime}$ を導出する方法を提案した．また，無負荷モーメントアーム $L_{X}^{\prime} を$ 基準に定常曲げ実験 結果を参照して曲げモーメントに寄与寸る移動量 $H_{M}$ を導出した.

接触のための移動量 $H_{C}$ と曲げモーメントに寄与する移動量 $H_{M}$ との和を設計形状に加工するための全押込み量 とする押込み量の導出方法を提案し，検証実験を行ったところ，従来の押込み量の導出方法と比較して設計液状 に近い加工形状を得ることができた. 曲率偏差の絶対值総和による数值的評価では, 曲率偏差の絶対值総和を 3050\%程度低減できること，特に曲率変化の大きい設計形状に対して提案方法は有効であることを確認した.

今後は，(1)二次元レンズカーブ加工に相当する二次元形状の曲げ・曲げ戻し（平面上曲線）加工，(2)二次元リ ム巻きカーブと二次元レンズカーブ加工を組み合わせた三次元曲げとそのフィードバック修正方法に取り組んで いく予定である.

\section{文献}

社団法人日本チタン協会編，チタンの加工技術，初版 3 刷 (1996), p. 69.

財団法人日本規格協会編，眼鏡光学一眼鏡フレーム一用語 JIS B7280, 第 1 刷 (2006), pp. 4-5.

財団法人日本規格協会編, 眼鏡フレーム一基本的要求事項及びその試験方法 JIS B7285, 第 1 刷 (2008), p. 3. 
財団法人日本規格協会編，チタン及びチタン合金一棒ＪIS H4650, 第 1 刷 (2012),p. 5.

久保木孝, 古堅宗勝, 逢坂慎一郎, 小野敏秀, ダイレス U ベント法の理論解析一管材の高精度ダイレスベント 法の開発 I 一, 塑性と加工, Vol. 41, No. 473 (2000), pp. 93-97.

村田眞，山本理，鈴木秀雄，管材の CNC 曲げ加工機の開発，塑性と加工, Vol. 35, No. 398 (1994) , pp. 262-267.

Sekine, Y., Asakawa, M., Kato, N., Takebe, Y., Matsuo, S., Sasaki, Y. and Matsumura, M., High-precision roll-bending of titanium alloy wire for glasses, The Conference Proceedings for the $83^{\text {rd }}$ Annual Convention of the Wire Association International (2012).

曽田長一郎, 小西摂子, 3 本ロール曲げによる板の変形, 塑性と加工, Vol. 3, No. 18 (1962), pp. 474-484.

曽田長一郎, 小西摂子, 3 本ロール曲げによる板の変形一続報, 塑性と加工, Vol. 4, No. 31 (1963), pp. 515-527.

福井県総合政策部政策統計課編, 福井県の工業 (2012), pp. 27-29.

社団法人日本塑性加工学会編，曲げ加工一高精度化一の挑戦一, 初版 1 刷 (1995), pp. 13-20.

山内鴻之祐, 眼鏡用金属材料と加工技術, 塑性と加工, Vol. 45, No. 516 (2004), pp. 13-18.

山川俊夫, 山下勇, 泉照之, 熊谷年男, ピラミッド型 3 本ロールによる異形形状の曲げ加工一数值制御ベンディン グロールに関する研究 I -, 塑性と加工, Vol. 18, No. 193 (1977) , pp. 106-113.

\section{References}

Japan Titanium Society ed., Manufacturing technology of Titanium (1996), p. 69 (in Japanese).

Japanese Standards Association ed., Ophthalmic optics - Spectacle frames - vocabulary and lists of equivalent terms JIS B 7280 (2006), pp. $4-5$ (in Japanese).

Japanese Standards Association ed., Spectacle frames - Requirements and test methods JIS B 7285 (2008), p. 3 (in Japanese).

Japanese Standards Association ed., Titanium and titanium alloys-Rods and bars JIS H 4650 (2012), p. 5 (in Japanese).

Kuboki, T., Furugen, M., Ohsaka, S. and Ono, T., Theoretical analysis of die-less U-bending process -Development of die-less bending process for precision bent tube I -, Journal of JSTP, Vol. 41, No. 473 (2000), pp. $93-97$ (in Japanese).

Murata, M., Yamamoto, S. and Suzuki, H., Development of CNC machine for tube bending, Journal of JSTP, Vol. 35, No. 398 (1994), pp. 262-267(in Japanese).

Sekine, Y., Asakawa, M., Kato, N., Takebe, Y., Matsuo, S., Sasaki, Y. and Matsumura, M., High-precision roll-bending of titanium alloy wire for glasses, The Conference Proceedings for the $83^{\text {rd }}$ Annual Convention of the Wire Association International (2012).

Soda, T. and Konishi, S., Deformation process of plate bending with three rolls, Journal of JSTP, Vol. 3, No. 18 (1962), pp. 474-484 (in Japanese).

Soda, T. and Konishi, S., Deformation process of plate bending with three rolls, Journal of JSTP, Vol. 4, No. 31 (1963), pp. 515-527 (in Japanese).

Statistics section of Fukui prefecture ed., Industry of Fukui (2012), pp. 27-29(in Japanese).

The Japan Society for Technology of Plasticity ed., Bending - Approach to high accuracy - (1995), pp. 13-20 (in Japanese).

Yamauchi, K., Metal for glasses and manufacturing technology, Journal of JSTP, Vol. 45, No. 516 (2004) , pp. 13-18 (in Japanese).

Yamakawa, T., Yamashita, I., Izumi, T. and Kumagaya, T., Contour forming of steel plate using a pyramid type three-rolls study on numerical controlled bending roll I -, Journal of JSTP, Vol. 18, No. 193 (1977), pp. 106-113 (in Japanese). 